\title{
Epilepsikirurgi - utredning og pasientseleksjon
}

\begin{abstract}
Sammendrag
Bakgrunn. For pasienter med epilepsi har betydelige fremskritt innen bildediagnostikk og video-EEG-monitorering gitt bedre muligheter for å lokalisere det hjerneområdet som gir anfall. Til tross for at epilepsikirurgi dermed kan tilbys flere i dag enn tidligere, blir relativt få henvist til kirurgiutredning. Formålet med denne artikkelen er å gi en kort oversikt over hvem som bør utredes for epilepsikirurgi og hva denne utredningen består $\mathrm{i}$.
\end{abstract}

Kunnskapsgrunnlag. Artikkelen er basert på et litteraturs $ø$ i PubMed i tillegg til forfatternes egne erfaringer innen fagfeltet.

Resultater. Når epilepsien ikke responderer på noen form for farmakologisk behandling og man har utelukket idiopatisk generalisert epilepsi eller pseudoresistens, bør pasienten henvises for kirurgivurdering. Utredningen er multidisiplinær og har som mål å kartlegge den epileptogene sonen, som kan identifiseres gjennom så vel strukturelle som funksjonelle avvik. Før inngrepet må det avklares om sonen kan fjernes uten å etterlate alvorlige nevrologiske eller kognitive utfall. Best resultater av epilepsikirurgi ses hos pasienter der epilepsien har et morfologisk substrat, særlig temporallappsepilepsi med hippocampussklerose.

Fortolkning. Kirurgi spiller en stadig viktigere rolle i behandlingen av vanskelig kontrollerbar epilepsi. Leger som behandler epilepsipasienter, bør henvise potensielle operasjonskandidater tidlig i sykdomsforløpet.

\section{Karl O. Nakken}

karl.otto.nakken@ous-hf.no

Hrisimir Kostov

Anette Ramm-Pettersen

Einar Heminghyt

Avdeling for kompleks epilepsi - SSE

Klinikk for kirurgi og nevrofag

\section{Søren Jacob Bakke}

Bård Nedregaard

Nevroradiologisk seksjon

Klinikk for diagnostikk og intervensjon

\section{Arild Egge}

Nevrokirurgisk seksjon

Klinikk for kirurgi og nevrofag

Oslo universitetssykehus

Kirurgisk behandling av epilepsi er et fagfelt i rivende utvikling. Stadig mer avanserte bildediagnostiske metoder, fremskritt innen klinisk nevrofysiologi og nye kirurgiske teknikker har gjort denne behandlingsformen mulig for flere i dag enn tidligere. Avdeling for kompleks epilepsi ved Oslo universitetssykehus har landsfunksjon for utredning av pasienter for epilepsikirurgi samt for oppfølging av opererte.

Vår erfaring er at mange kolleger enten ikke kjenner til denne muligheten eller ser på epilepsikirurgi som siste utvei. Følgene er at mange som kunne ha blitt operert, aldri blir henvist, eller de blir henvist så sent at mange av de psykososiale konsekvensene av å leve med en dårlig kontrollert epilepsi er blitt irreversible (1). Formålet med denne artikkelen er å beskrive hvilke pasienter som bør utredes for epilepsikirurgi samt gi en kort oversikt over hvordan utredningen foregår.

\section{Kunnskapsgrunnlag}

Artikkelen bygger på et skjønnsmessig utvalg av engelskspråklige originalartikler, metaanalyser og oversiktsartikler funnet $\mathrm{i}$ PubMed under søkekombinasjonene «epilepsy surgery», «evaluation», «selection» og «outcome» for perioden 1990-februar 2012 samt egne erfaringer med pasientgruppen ved Avdeling for kompleks epilepsi og ved Nevroradiologisk seksjon og Nevrokirurgisk seksjon ved Oslo universitetssykehus.

\section{Behovet for epilepsikirurgi}

Rundt $30 \%$ av epilepsipasientene oppnår ikke anfallskontroll med dagens medikamenter. Man regner at snaut en tredel av disse er operasjonskandidater, dvs. 5-10\% av epilepsipopulasjonen (2). I en engelsk studie ble behovet for epilepsikirurgi esti- mert til minst ti nye tilfeller per million mennesker per år (3). Det betyr at det her i landet skulle være behov for minst 50 epilepsioperasjoner årlig. Implantasjon av vagusstimulator er ikke inkludert i disse tallene.

De siste årene er 15-25 pasienter blitt epilepsioperert $i$ Norge per år (upubliserte tall fra egen landsdekkende avdeling). Som i de fleste andre land vi kan sammenlikne oss med, er det hos oss således et gap mellom antatt behov for epilepsikirurgi og antall utførte operasjoner $(4,5)$.

\section{Hvem er operasjonskandidat?}

Resektiv kirurgi, dvs. operativ fjerning av det anfallsgivende hjerneområdet, er inngrepet som er mest benyttet. Aktuelle kandidater for slik behandling er pasienter med farmakoresistente fokale anfall med eller uten sekundærgeneraliserte tonisk-kloniske anfall. Anfallene anses som farmakoresistente hvis de ikke er kommet under kontroll etter forsøk med minst to riktig valgte, tolererte og riktig brukte antiepileptika som monoterapi eller $\mathrm{i}$ kombinasjon (6). Flere epilepsisyndromer er forbundet med farmakoresistente anfall. Noen eksempler på syndromer der man kan vurdere kirurgi, er gjengitt i ramme 1 (7). Det er ikke krav om noen bestemt anfallsfrekvens, men pasient og pårørende må oppleve anfallssituasjonen som så alvorlig at livskvaliteten forringes i betydelig grad.

Anfallene bør være stereotype. Anfallsutformingen og de nevrofysiologiske, nevropsykologiske og nevroradiologiske funn bør peke mot en epileptogen sone som lar seg fjerne uten at pasienten påføres alvorlig nevrologisk eller kognitiv sekvele. Pasient og pårørende må også være motivert for inn-

\section{Hovedbudskap}

- Nye nevrofysiologiske og nevroradiologiske teknikker har gjort epilepsikirurgi mulig for flere pasienter i dag enn tidligere

- Hos epilepsipasienter som ikke oppnår anfallskontroll med medikamenter. bør man vurdere muligheten for kirurgi allerede 1-2 år etter anfallsdebut

- Den multidisiplinære preoperative utredningen tar sikte på å kartlegge den epileptogene sonen og hvilke funksjoner denne ivaretar 
grepet etter å ha blitt informert om funnene fra de preoperative undersøkelsene og etter grundig drøfting av risiko og nytte.

Det benyttes flere operasjonsmetoder. Mens man tidligere ofte foretok enblocreseksjoner, går utviklingen i dag mot mer individuelt tilpassede operasjoner. Temporallappskirurgi er vanligst hos voksne, mens ekstratemporal kirurgi og større unihemisfæriske inngrep er vanligere hos barn.

Det er ingen øvre eller nedre aldersgrense for epilepsikirurgi. Svekket allmenntilstand kan være en kontraindikasjon.

\section{Hvorfor tidlig \\ kirurgisk intervensjon?}

Dårlig kontrollert epilepsi er forbundet med betydelig økt morbiditet og mortalitet. Mange har langvarig postiktal funksjonssvikt, hyppige anfallsrelaterte skader og plagsomme medikamentbivirkninger. Noen blir mobbet eller stigmatisert. Det er også 5-6 ganger økt risiko for plutselig anfallsrelatert død $(8,9)$. I tillegg er det en betydelig psykiatrisk komorbiditet i denne pasientgruppen (10). Med årene får særlig pasienter med farmakoresistent temporallappsepilepsi redusert hippocampusvolum, med derav følgende kognitive problemer $(11,12)$.

Stadig tilbakevendende konvulsive anfal er en alvorlig trussel for barnehjerner i utvikling og kan redusere sjansen for at barnet senere kan leve et selvstendig og meningsfylt liv (7).

En randomisert, kontrollert studie av 80 pasienter med farmakoresistent temporallappsepilepsi viste at etter ett år hadde $58 \%$ av de 40 som ble operert, blitt helt fri for anfall som påvirket bevisstheten, mot bare $8 \%$ av de 40 som fikk optimal medikamentell behandling (13). Mens antiepileptika er en symptomatisk, anfallsdempende terapi, er epilepsikirurgi den eneste potensielt kurative behandling.

Hvis anfallene ikke lar seg kontrollere med medikamenter, bør epilepsikirurgi vurderes allerede 1-2 år etter epilepsidebuten hos både voksne og barn. Hos barn med alvorlige epileptiske encefalopatier bør kirurgi vurderes enda tidligere. Vår erfaring er at tidlig kirurgisk intervensjon gir de beste sjanser for en optimal utvikling hos barn og for en vellykket psykososial rehabilitering hos voksne.

\section{Preoperativ diagnostikk}

Utredning og seleksjon av pasienter for epilepsikirurgi er en multidisiplinær oppgave der nevrolog/barnenevrolog, psykiater, sykepleier, nevrofysiolog, EEG-tekniker, nevropsykolog, nevroradiolog og nevrokirurg alle yter viktige bidrag.

Målet med utredningen er å karakterisere pasientens epilepsi og anfall så grundig som mulig. Der reseksjon er mest aktuelt, er målet å lokalisere den epileptogene sonen og kartlegge hvilke funksjoner denne ivaretar (7). Forskjellige metoder brukes for å kartlegge den epileptogene sonen, og et inngrep kan ikke baseres på resultater fra én metode alene. Data fra flere modaliteter integreres og former en hypotese om hvor det anfallsgivende barkområdet er lokalisert. Dersom reseksjon av den epileptogene sonen ikke er tilrådelig, kan man i enkelte tilfeller vurdere palliativ kirurgi, dvs. inngrep der man ikke sikter mot anfallsfrihet, men mot en reduksjon av anfallenes frekvens og styrke. Ved slike inngrep er det ikke nødvendig med en så presis kartlegging av den epileptogene sonen.

\section{Sykehistorie og klinisk}

\section{nevrologisk undersøkelse}

En god anamnese vil kunne vekke mistanke om den bakenforliggende årsaken til epilepsien, for eksempel genetiske forhold, sentralnervøse traumer, svulster, infeksjoner eller vaskulære hendelser. Gode anfallsbeskrivelser kan bidra til å lokalisere den symptomgivende sonen - ikke bare innen hvilken hemisfære, men også innen hvilke områder av hemisfæren. Eksempelvis vil initiale iktale synsforstyrrelser peke mot oksipitallappen, mens initiale iktale hørselsfenomener peker mot laterale neokortikale deler av temporallappen (Heschls gyrus) Iktal og/eller postiktal dysfasi peker mot språkdominant hemisfære. Det er imidlertid viktig å være oppmerksom på at anfall kan starte i klinisk stumme områder og at de første iktale symptomene gir seg til kjenne først når den epileptiske aktiviteten har spredt seg til den symptomatogene sonen.

Sykehistorien vil også kunne avdekke epilepsiens alvorlighetsgrad, hvorvidt den virkelig er farmakoresistent og eventuelle komorbide tilstander. Anamnesen kan av og til vekke mistanke om såkalt pseudoresistens, dvs. at anfallene enten ikke er av epileptisk art, at pasienten ikke tar medisinene som foreskrevet, eller at man har valgt et antiepileptikum som ikke er egnet for pasientens epilepsi- eller anfallstype. Klinisk nevrologisk undersøkelse kan av og til avdekke fokale nevrologiske utfall som peker mot en lokalisert kortikal dysfunksjon.

\section{Psykiatrisk utredning}

En preoperativ vurdering av en psykiater med erfaring fra denne pasientgruppen er alltid nyttig.

Psykiaterens oppgave er å vurdere pasientens evne til å tåle de belastninger en operasjonsutredning er, og estimere risikoen for psykiatriske problemer postoperativt. Psykiatrisk komorbiditet, inkludert angst, depresjon, atferdsforstyrrelser og psykoser, ble tidligere ansett som en relativ kontraindikasjon til kirurgi. I de senere år har man imidlertid endret holdning, idet man har sett at psykiatriske symptomer som regel ikke blir verre etter inngrepene, i mange tilfeller tvert imot $(14,15)$ Pasienter med betydelig psykiatrisk komorbiditet har allikevel mindre sjanse for å bli anfallsfrie etter resektiv kirurgi enn pasienter uten slike problemer $(14,15)$. Fortsatt er man

\section{Ramme 1}

Epilepsisyndromer der man bør vurdere kirurgi dersom man ikke oppnår medikamentell anfallskontroll (7)

- Mesial temporallappsepilepsi, med eller uten hippocampussklerose

- Lesjonelle neokortikale epilepsier If.eks. epilepsi assosiert med svulster, vaskulære anomalier, kortikale dysplasier)

- Ikke-lesjonelle neokortikale epilepsier

- Unihemisfæriske epilepsier (f.eks. Sturge-Webers syndrom, Rasmussens syndrom, hemimegalencefali, infantil hemiplegi med unihemisfærisk atrofi eller porencefali

Sekundærgeneraliserte epilepsier If.eks. Lennox-Gastauts syndrom og enkelte tilfeller av Wests syndrom)

tilbakeholden med temporallappsreseksjoner hos pasienter med interiktale psykoser.

\section{Nevropsykologisk testing}

Preoperativ nevropsykologisk undersøkelse omfatter evnevurdering og testing av innlæring, hukommelse, språk, visuo-analytiske, visuo-konstruktive og eksekutive funksjoner. Undersøkelsene kan bidra til identifisering av dysfunksjonelle kortikale cellenettverk og fortelle noe om risikoen for uakseptable postoperative kognitive sekveler, eventuelt også om behovet for spesifikke undersøkelser som Wada-test og funksjonell MR (fMRI). Resultatene danner også utgangspunkt for postoperativ vurdering av effektene av inngrepet på kognisjonen.

Wada-test utføres i samarbeid mellom nevroradiologer, nevropsykologer og nevrofysiologer og består i undersøkelse av språkog hukommelsesfunksjoner under kortvarig anestesi av én hemisfære eller deler av denne. Formålet er å identifisere språkdominant hemisfære og avklare om pasientens hukommelseslagring kan ivaretas av den hemisfære som ikke skal opereres. Begge problemstillingene er viktige i forbindelse med temporallappsreseksjon, mens lokalisering av språkfunksjoner er den vanligste indikasjonen ved inngrep i frontallappene. Wadatest er en invasiv metode og kan i noen tilfeller erstattes av fMRI for kartlegging av språkfunksjoner (16).

\section{Langtids EEG-monitorering med videoopptak av anfall}

Langtids EEG-monitorering (LTM) med videoopptak av pasientens habituelle anfall er et helt nødvendig verktøy i operasjonsutredningen og regnes i dag som selve gullstandarden. 

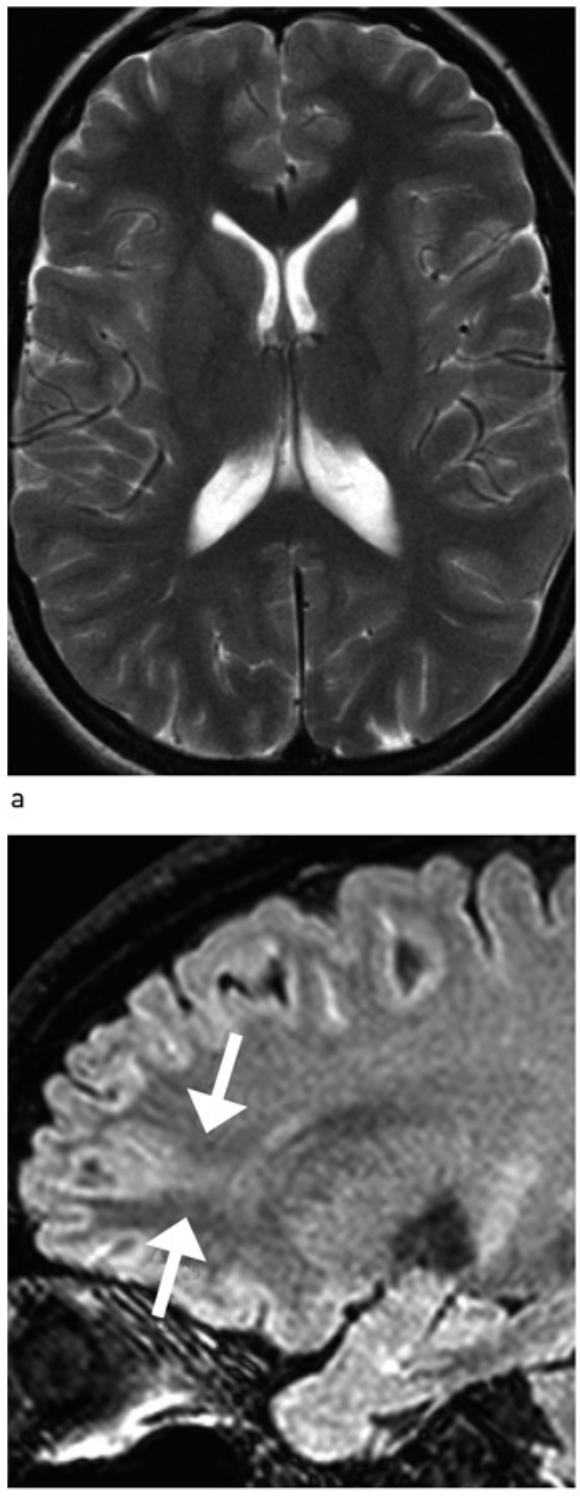

d

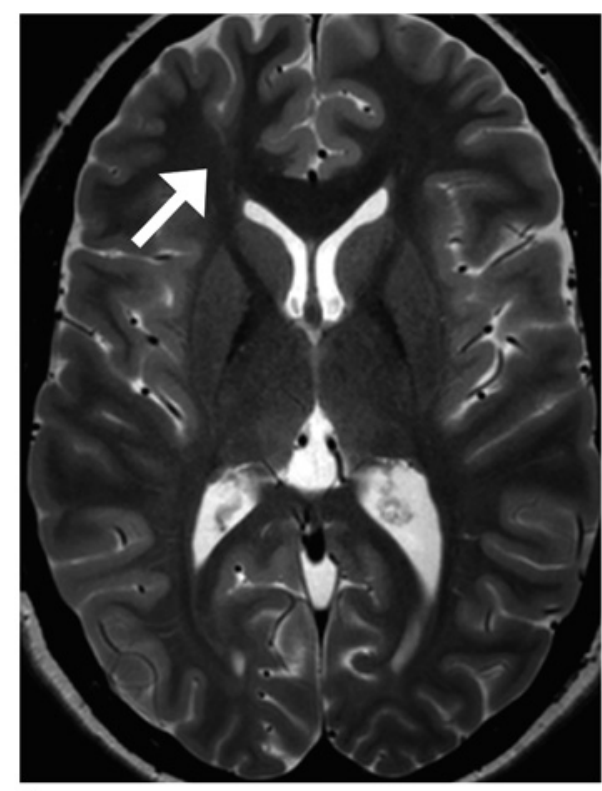

b

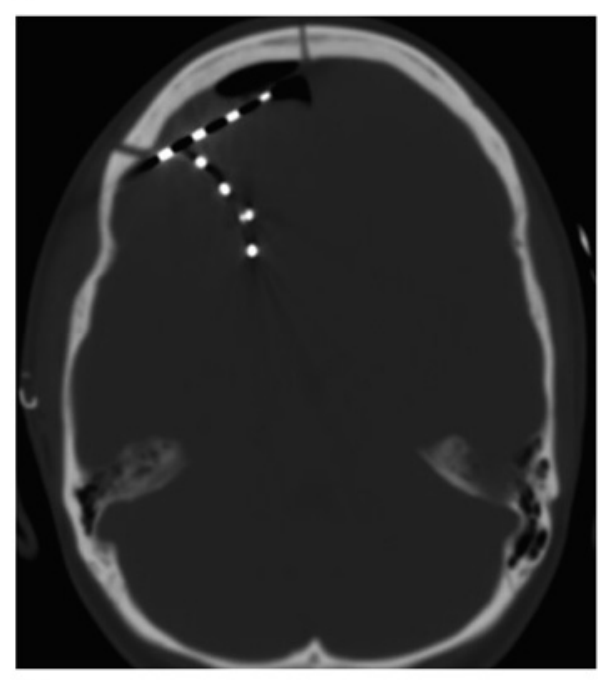

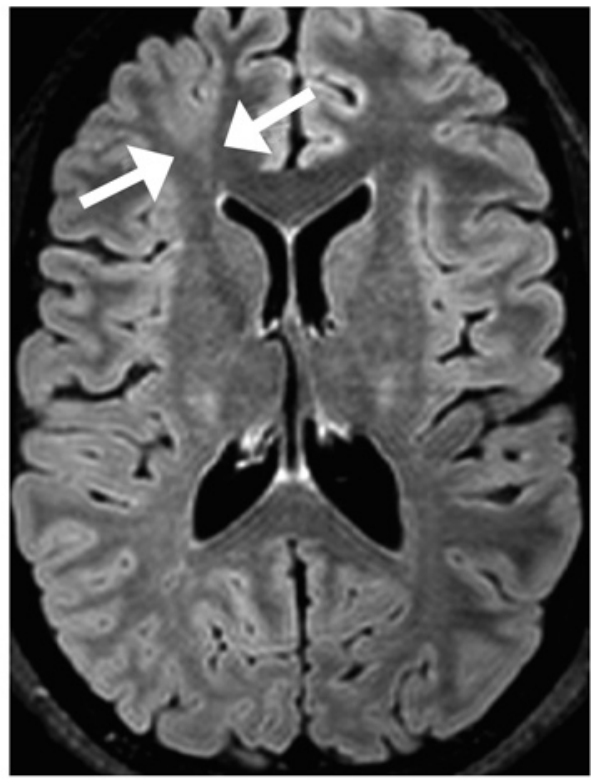

C

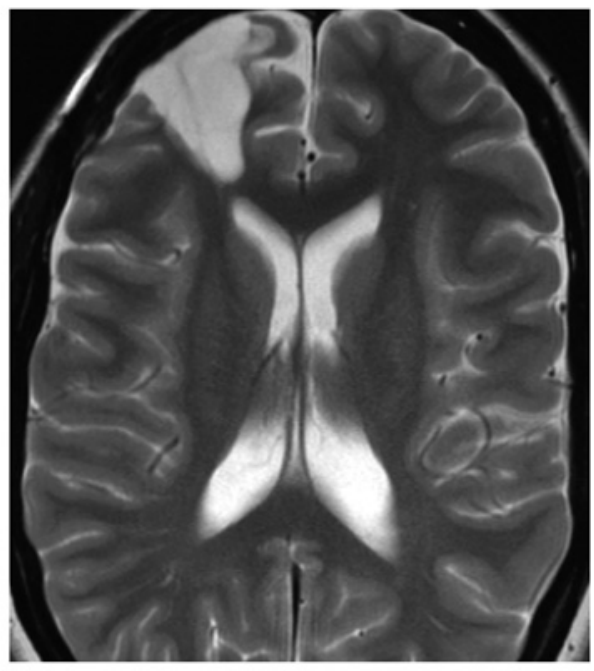

Figur 1 Pasient med terapiresistent epilepsi som har vært undersøkt etter «epilepsiprotokoll» med en 1,5 tesla MR-maskin - uten synlig morfologisk epilepsisubstrat, heller ikke ved retrospektiv gransking. Senere ble pasienten undersøkt med en 3 tesla MR-maskin. a) 1,5 tesla MR-maskin. Aksialt T2-vektet bilde (TSE). Aktuelt område: Intet patologisk. Så ble det gjort ny undersøkelse med 3 tesla MR-maskin. b) Aksialt T2-vektet bilde med 3 tesla-maskin (pill. c) Aksial FLAIR med 1 mm tykke snitt (FLAIR volumserie) (piler). d) Sagittal FLAIR $1 \mathrm{~mm}$, utsnitt (samme opptak som c) (piler). b-d viser funn forenlig med liten fokal kortikal dysplasi fortil i høyre frontallapp, inklusivt radierende drag i hvit substans inn mot høyre forhorn. e) CT caput etter kraniotomi. Det er innlagt to dybdeelektroder (for intrakranial EEG-registrering) forløpende radiært inn mot høyre frontalhorn samt en matteelektrode på overflaten (langs beinlappen). (Dybdeelektrodene penetreres inn i hjernevevet langs den antatte dysplasien ved hjelp av nevronavigasjon.) f) Kontrollbilde med 1,5 tesla MR-maskin åtte måneder postoperativt viser at hele lesjonen er fjernet

Ved Avdeling for kompleks epilepsi har vi for tiden ti senger ved klinisk nevrofysiologisk laboratorium. Gjennomsnittlig liggetid for vurdering for operasjon er her 3-4 døgn. Bare rundt $25 \%$ av dem som utredes med tanke på kirurgi, blir operert (17).

Målet med undersøkelsen er en grundig kartlegging av pasientens epilepsi- og anfallstype(r) og lokalisering av det anfallsgivende hjerneområdet. Den største utfordringen er som oftest å få provosert og registrert et tilstrekkelig antall anfall. For å fremkalle anfall trappes gjerne pasientens medikamentdoser ned eller pasienten utsettes for annet som erfaringsmessig senker anfallsterskelen, for eksempel søvndeprivasjon eller andre stressbelastninger.
Fordelen ved langtids EEG-monitorering fremfor andre diagnostiske metoder er at man får en svært nøyaktig registrering av pasientens vanlige anfall og at man får relatert de iktale EEG-funn til anfallenes kliniske ytringsform. Fokale epileptiforme EEG-forstyrrelser som starter før de kliniske symptomene, bidrar til å definere den iktale startsonen.

\section{MR-undersøkelse}

MR-undersøkelse er den viktigste bildediagnostiske metode for påvisning av et morfologisk substrat for epilepsikirurgi. Særlig viktig er undersøkelsen ved temporallappsepilepsi. For å kunne sammenlikne de to sidenes hippocampi legges aksiale snitt etter tempor- allappens lengdeakse og vinkelrett på denne. T1-vektede volumopptak (MPRAGE) gir best anatomisk fremstilling, og mange små dysplasier kommer godt frem ved T1MPRAGE. T2- og FLAIR-sekvenser er særlig viktig for påvisning av subtile fokale kortikale dysplasier, noe som i dag er en stor utfordring for nevroradiologene. Innføring av sterkere magnetfeltstyrker, i praksis magneter på 3 tesla fremfor 1,5 tesla, har vist seg å ha stor betydning for påvisning av små lesjoner (fig 1a-f). Med 3 tesla-magneter har vi også fått mer avanserte MR-metoder, eksempelvis traktografi, basert på «diffusion tensor imaging». De nye MR-teknikkene har redusert behovet for invasiv EEG-monitorering (18). Hvis man likevel velger å legge inn 
intrakraniale elektroder, vil sikrere MR-funn gi bedre og mer målrettede registreringer.

\section{Hvis funnene spriker}

Sjansene for et godt postoperativt resultat er best når funnene fra funksjonsundersøkelser og bildediagnostikk peker mot én epileptogen sone (19). Når funnene er inkonklusive eller sprikende, kan invasive EEG-registreringer fra intrakranialt plasserte elektroder være nødvendig (fig 2). Slike registreringer benyttes hos $10-15 \%$ av operasjonskandidatene (ikke-publiserte resultater fra egen avdeling). Bitemporale stripeelektroder (små strimler som plasseres subduralt gjennom borehull) benyttes spesielt hos pasienter med mistenkte temporallappsanfall der skalpregistreringer ikke har gitt sikre funn. Større plater med 20-64 elektrodevinduer, såkalte matter, som plasseres subduralt etter kraniotomi, brukes ved mistanke om anfallsstart fra ekstratemporale områder eller lateralt temporalt. Dybdeelektroder (lange nålelektroder) brukes i sjeldne tilfeller når det er mistanke om anfallsstart fra dypereliggende strukturer (fig 1e).

Hvis EEG-undersøkelsene etterlater tvil om hvor anfallene starter, kan positronemisjonstomografi (PET) bidra til å lokalisere den epileptogene sonen (20). Nyere teknikker som statistisk parametrisk kartlegging og tredimensjonale stereotaktiske overflateprojeksjonsbilder, koregistrert med MRundersøkelser, kan øke sensitiviteten og spesifisiteten av PET-undersøkelsen $(21,22)$.

Iktal enfotonstomografi (single photon emission computerized tomography, SPECT) er en undersøkelse som brukes hos pasienter der EEG, PET og MR har gitt diskordante eller inkonklusive funn. Tidligst mulig under et anfall injiseres en radioaktiv isotop (technetium-99m) som binder seg til hjernevevet avhengig av den regionale perfusjonen. Det epileptogene området viser seg i form av hyperperfusjon under anfall og som hypoperfusjon mellom anfall. Subtraksjonsbilder fra interiktal og iktal SPECT-undersøkelse som legges på pasientens MR-bilder, øker sensitiviteten av undersøkelsen (23).

Ved magnetencefalografi (MEG) registreres det magnetiske feltet som produseres av den nevronale aktiviteten. Signalene dempes ikke av skallen, og epileptiform aktivitet som er vanskelig å fange opp med EEG, kan være synlig på MEG (24). Magnetisk kildefremvisning (magnetic source imaging), som kombinerer resultatene fra MR og MEG, kan gi tilleggsinformasjon hos $35 \%$ av pasientene og kan være avgjørende for beslutningen om operasjon hos $10 \%$ av dem (25). Det er for tiden ingen MEG-maskin i Norge.

\section{Peroperativ kortikografi og funksjonskartlegging}

Under inngrepet kan man registrere epileptiform aktivitet direkte fra cortex (elektrokortikografi) og dermed bestemme nødvendig omfang av reseksjonen. Metoden er særlig
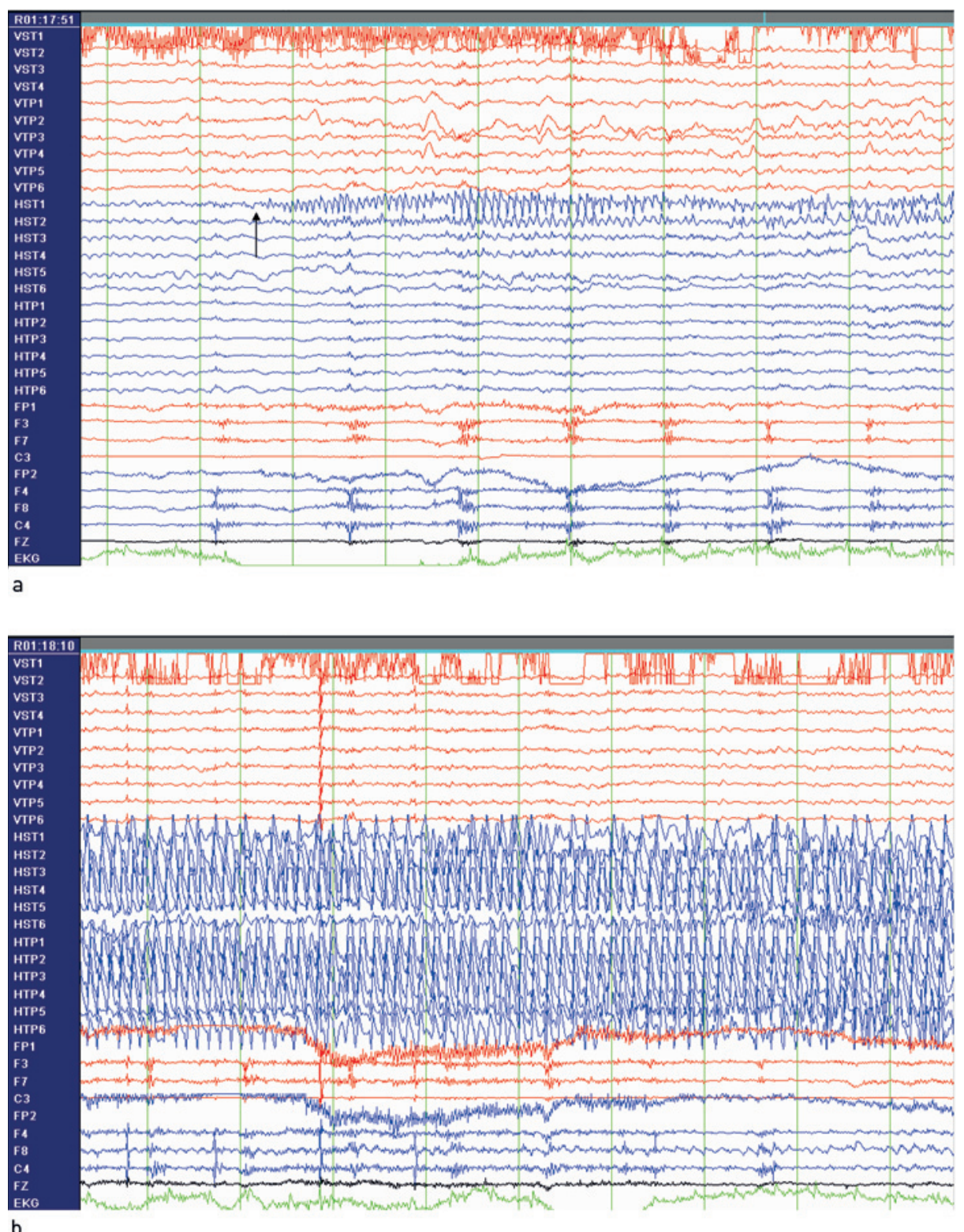

Figur 2 a) EEG fra pasient med temporallappsanfall og høyresidig hippocampussklerose. Det er registrert fra både skalpelektroder og implanterte bitemporale stripeelektroder. Kurven viser fokal epileptiform aktivitet som bygger seg opp i HST 1 + 2, dvs. anfallet starter i høyre subtemporalregion (anfallsstart markert med pill. b) Ca. 20 sekunder etter start av anfallet har den epileptiforme aktiviteten spredt seg til skalpelektroden F8

nyttig hos pasienter med dårlig avgrensede strukturelle lesjoner samt hos pasienter uten patologiske funn på $\mathrm{MR}$.

Nye studier har vist at høyfrekvente oscillasjoner (aktivitet med $80-250 \mathrm{~Hz}$ ) er koblet til området for anfallsstart og kanskje kan være en biomarkør for epileptogenesen $(26,27)$. Reseksjon av cortex som genererer slik aktivitet, er sannsynligvis av større betydning for operasjonsresultatet enn reseksjon av områder som generer «spike»aktivitet.

Hvis man finner at pasientens anfall starter i nær relasjon til elokvent cortex, dvs. hjernebark som ivaretar viktige funksjoner, kan det være aktuelt med peroperativ kortikal stimulering for å kartlegge de primære sensorimotoriske områdene eller språkområdene. En slik kartlegging er særlig viktig ved medfødte lesjoner der cortex har gjennomgått en funksjonell reorganisering.

\section{Operasjonsresultater}

Best resultater ses hos «MR-positive» pasienter, dvs. de med lesjonell epilepsi (19). Resultatene varierer imidlertid med type og lokalisasjon av den bakenforliggende årsaken. Resultatene er bedre ved temporale enn ved ekstratemporale inngrep (28). To år etter inngrepet er grovt sett $60-70 \%$ av dem med temporale inngrep enten anfallsfrie eller nesten anfallsfrie, mens tilvarende tall hos dem med ekstratemporale reseksjoner er 40-50\% (29). Med årene får noen anfallsresidiv. En fersk engelsk studie viste at etter ti år var $47 \%$ av 615 epilepsiopererte anfallsfrie eller nesten anfallsfrie (30).

I tillegg til effekten på anfallene har inn- 
grepene ofte positive effekter på psykiatriske og psykososiale problemer $(31,32)$. Reseksjoner i temporallappene kan svekke hukommelseslagringen, særlig lagring av verbalt materiale etter reseksjoner i dominant hemisfære (33). Komplikasjonsraten er imidlertid generelt lav, og risikoen ved inngrepet må veies mot risikoen ved fortsatt medisinsk behandling, inkludert den økte risikoen for plutselig død $(8,9)$.

\section{Konklusjon}

$\AA$ velge ut hvilke epilepsipasienter som egner seg for kirurgisk behandling, er en krevende prosess. De siste årene har bedre nevrofysiologiske og nevroradiologiske teknikker gjort det mulig å lokalisere den epileptogene sonen mer nøyaktig enn før. Det er ingen tvil om at dette behandlingsalternativet blir brukt for sjelden i Norge.

\section{Karl O. Nakken (f. 1945)}

er spesialist i nevrologi med spesialkompetanse i epileptologi. Han er medisinsk sjef ved Avdeling for kompleks epilepsi-SSE ved Oslo universitetssykehus.

Forfatter har fylt ut ICMJE-skjemaet og oppgir ingen interessekonflikter.

\section{Hrisimir Kostov (f. 1961)}

er overlege og spesialist i nevrologi. Han har det faglige ansvaret for iktal SPECT og oppfølging av pasienter med implantert vagusnervestimulator ved Seksjon for klinisk nevrofysiologi ved Avdeling for kompleks epilepsiSSE, Oslo universitetssykehus.

Forfatter har fylt ut ICMJE-skjemaet og oppgir ingen interessekonflikter.

\section{Anette Ramm-Pettersen (f. 1967)}

er spesialist i pediatri, seksjonsleder og overlege ved Seksjon for barn og ungdom med epilepsi, Avdeling for kompleks epilepsi-SSE ved Oslo universitetssykehus. Hun jobber for tiden med et ph.d.-prosjekt om Glut-1-mangelsykdom. Forfatter har fylt ut ICMJE-skjemaet og oppgir ingen interessekonflikter.

\section{Einar Heminghyt (f. 1951)}

er spesialist i klinisk nevropsykologi og leder av Seksjon for klinisk psykologi og nevropsykologi ved Avdeling for kompleks epilepsi-SSE, Oslo universitetssykehus

Forfatter har fylt ut ICMJE-skjemaet og oppgir ingen interessekonflikter.

\section{Søren Jacob Bakke (f. 1946)}

er overlege og spesialist i nevroradiologi. Han er intervensjonsradiolog og har det radiologiske ansvaret for Wada-testene ved Nevroradiologisk seksjon ved Oslo universitetssykehus, Rikshospitalet.

Forfatter har fylt ut ICMJE-skjemaet og oppgir ingen interessekonflikter.

\section{Bård Nedregaard (f. 1969)}

er overlege og spesialist i nevroradiologi. Han har spesielt arbeidet med MR-teknikker inkludert funksjonell MR, ved Nevroradiologisk seksjon ved Oslo universitetssykehus, Rikshospitalet.

Forfatter har fylt ut ICMJE-skjemaet og oppgir ingen interessekonflikter.

\section{Arild Egge (f. 1960)}

er overlege og spesialist i nevrokirurgi. Han har ansvaret for den epilepsikirurgiske virksomheten ved Nevrokirurgisk seksjon ved Oslo universitetssykehus, Rikshospitalet. Forfatter har fylt ut ICMJE-skjemaet og oppgir ingen interessekonflikter.

\section{Litteratur}

1. Ryvlin P, Rheims S. Epilepsy surgery: eligibility criteria and presurgical evaluation. Dialogues Clin Neurosci 2008; 10: 91-103.

2. Hauser WA. The natural history of seizures. I: Wyllie E, red. The treatment of epilepsy: principles and practice. Philadelphia, PA: Lea and Febiger, 1993: 165-70

3. Lhatoo SD, Solomon JK, McEvoy AW et al. A prospective study of the requirement for and the provision of epilepsy surgery in the United Kingdom. Epilepsia 2003; 44: 673-6.

4. Haneef Z, Stern J, Dewar S et al. Referral pattern for epilepsy surgery after evidence-based recommendations: a retrospective study. Neurology 2010: 75: 699-704

5. Wiebe S, Jetté N. Epilepsy surgery utilization: who, when, where, and why? Curr Opin Neurol 2012; 25 187-93

6. Kwan P. Arzimanoglou A, Berg AT et al. Definition of drug resistant epilepsy: consensus proposal by the ad hoc Task Force of the ILAE Commission on Therapeutic Strategies. Epilepsia 2010; 51: 1069-77.

7. Perry MS, Duchowny M. Surgical management of intractable childhood epilepsy: curative and palliative procedures. Semin Pediatr Neurol 2011: 18: 195-202.

8. Neligan A, Bell GS, Johnson AL et al. The longterm risk of premature mortality in people with epilepsy. Brain 2011; 134: 388-95.

9. Gilliam FG, Albertson B. Identifying epilepsy surgery candidates in the outpatient clinic. Epilepsy Behav 2011: 20: 156-9.

10. Henning OJ, Nakken KO. Psychiatric comorbidity and use of psychotropic drugs in epilepsy patients. Acta Neurol Scand Suppl 2010; 122: 18-22.

11. Jokeit H, Luerding R, Ebner A. Cognitive impair ment in temporal-lobe epilepsy. Lancet 2000: 355 1018-9.

12. Fuerst D, Shah J, Shah A et al. Hippocampal sclerosis is a progressive disorder: a longitudinal volumetric MRI study. Ann Neurol 2003: 53: 413-6.

13. Wiebe S, Blume WT, Girvin JP et al. A randomized, controlled trial of surgery for temporal-lobe epilepsy. N Engl J Med 2001; 345: 311-8.

14. Guarnieri R, Walz R, Hallak JEC et al. Do psychiatric comorbidities predict postoperative seizure outcome in temporal lobe epilepsy surgery? Epilepsy Behav 2009: 14: 529-34.

15. Macrodimitris S, Sherman EM, Forde $S$ et al. Psychiatric outcomes of epilepsy surgery: a systematic review. Enilepsia 2011: 52: 880-90.

16. Baxendale S. The Wada test. Curr Opin Neurol 2009; 22: 185-9

17. Alfstad KÅ, Lossius MI, Røste GK et al. Acute postoperative seizures after epilepsy surgery - a longterm outcome predictor? Acta Neurol Scand 2011 123: 48-53

18. Bernasconi A, Bernasconi N, Bernhardt BC et al. Advances in MRI for 'cryptogenic' epilepsies. Nat Rev Neurol 2011: 7: 99-108.
19. Tonini C, Beghi E, Berg AT et al. Predictors of epilepsy surgery outcome: a meta-analysis. Epilepsy Res 2004; 62: 75-87.

20. Knowlton RC. The role of FDG-PET, ictal SPECT, and MEG in the epilepsy surgery evaluation. Epilepsy Behav 2006; 8: 91-101.

21. Drzezga A, Arnold S, Minoshima S et al. 18F-FDG PET studies in patients with extratemporal and temporal epilepsy: evaluation of an observer-independent analysis. J Nucl Med 1999: 40: 737-46.

22. Kim YK, Lee DS, Lee SK et al. (18)F-FDG PET in localization of frontal lobe epilepsy: comparison of visual and SPM analysis. J Nucl Med 2002; 43: 1167-74

23. Matsuda H, Matsuda K, Nakamura F et al. Contribution of subtraction ictal SPECT coregistered to MRI to epilepsy surgery: a multicenter study. Ann Nucl Med 2009; 23: 283-91.

24. Ebersole JS, Ebersole SM. Combining MEG and EEG source modeling in epilepsy evaluations. J Clin Neurophysiol 2010; 27: 360-71.

25. Stefan H, Hummel C, Scheler $G$ et al. Magnetic brain source imaging of focal epileptic activity: synopsis of 455 cases. Brain 2003; 126 . 2396-405

26. Jacobs J, Zijlmans M, Zelmann R et al. Highfrequency electroencephalographic oscillations correlate with outcome of epilepsy surgery. Ann Neurol 2010; 67: 209-20.

27. Wu JY, Sankar R, Lerner JT et al. Removing interictal fast ripples on electrocorticography linked with seizure freedom in children. Neurology 2010 75. $1686-94$

28. Téllez-Zenteno JF, Dhar R, Wiebe S. Long-term seizure outcomes following epilepsy surgery: a systematic review and meta-analysis. Brain 2005: 128: $1188-98$

29. Engel J Jr. Surgery for seizures. N Engl J Med 1996; 334: 647-52.

30. de Tisi J, Bell GS, Peacock JL et al. The long-term outcome of adult epilepsy surgery, patterns of seizure remission, and relapse: a cohort study. Lancet 2011: 378: 1388-95.

31. Devinsky O, Barr WB, Vickrey BG et al. Changes in depression and anxiety after resective surgery for epilepsy. Neurology 2005; 65: 1744-9.

32. Mikati MA, Ataya N, Ferzli J et al. Quality of life after surgery for intractable partial epilepsy in children: a cohort study with controls. Epilepsy Res 2010; 90: 207-13.

33. Helmstaedter C, Kurthen M, Lux S et al. Chronic epilepsy and cognition: a longitudinal study in temporal lobe epilepsy. Ann Neurol 2003; 54: 425-32.

Mottatt 5.11. 2011, første revisjon innsendt 25.11 2011, godkjent 16.5. 2012. Medisinsk redaktør Trine B. Haugen. 